\title{
THE ECOLOGY AND POTENTIAL HEALTH RISK OF THE ORAL MICROFLORA OF Python regius and Clelia scyntalina
}

\author{
BABALOLA M.O.* AND BALOGUN J.A.
}

Adekunle Ajasin University, Department of Microbiology, P.M.B. 001, Akungba Akoko, Ondo State, Nigeria.

*Corresponding Author: Email- mikeolubabs@yahoo.com

Received: December 29, 2012; Accepted: January 15, 2013

\begin{abstract}
-
Background: Traumatic bites and wound infections, particularly from animal associated accidents continue to debilitate many victims worldwide. The reservoired potentially pathogenic oral microflora of the aggressors were yet to be fully characterized.

Methods: The oral microflora of Python regius (a captive nonvenomous snake) and Clelia scyntalina (a non captive venomous snake) were investigated by culture of the oropharyngeal swabs, to evaluate the commensals, the potential pathogens, and the antibiotic susceptibility of the bacteria flora.

Results: Eighteen (18) bacteria isolates belonging to 12 Genera were detected. Nine (9) species were Gram negatives (Proteus mirabilis, Morganella morganii, Serratia marcescens, Pseudomonas proteolytica, Serratia liquefaciens, Citrobacter freundii, Yersinia enterocolitica, and Neisseria flora), and Gram positives (Enterococcus feacalis, Staphylococcus epidermidis, Bacillus subtilis, Corynebacterium ulcerans, Staphylococcus agalactiae, Bacillus mycoides, and Bacillus pumilus) respectively. The Gram negative bacteria were resistant to Ampicillin, Cotrimoxazole, Nalidixic acid and Nitrofurantoin. $50 \%$ of these bacteria were susceptible to Streptomycin, Colistin, and Gentamicin. Serratia marcescens was resistant to all the antibiotics except Nalidixic acid, while Morganella morganii, Pseudomonas proteolytica and Citrobacter freundii were only susceptible to Colistin. Of the Gram positive bacteria isolates, Staphylococcus epidermidis was susceptible to the tested antibiotics except Amoxicillin and Cloxacillin, while Enterococcus faecalis, Bacillus mycoides, Bacillus pumilus, Bacillus subtilis, and Streptococcus agalactiae were only susceptible to Gentamicin. The detected mycoflora were eight (8) fungal species belonging to six (6) Genera, comprising Aphanomyces sp., Aspergillus niger, Aspergillus fumigatus, Schizosaccharomyces sp. (from Python regius); Candida sp., Monilia sp., Candida krusei, and Penicillium sp. (from Clelia scyntalina).

Conclusion: Etiologic agents of septic wound infections that may either become opportunistic reptilian pathogens, or potentiate antibiotic therapeutic failure of infections in susceptible snakebite victims were detected. This research advance the ecology of microorganisms in respect of bacteria pathogens, antibiogram and the oral mycobiome of companion animals.

Keywords- Python, Clelia, snakebites, infections, multidrug, resistant, bacteria, mycoflora

Abbreviations- MAC: McConkey Agar, BA: Blood Agar with 5\% horse blood, SDA: Saboraud Dextrose Agar, CHA: CHROMagar, TSA: Tryptic Soy Agar.
\end{abstract}

Citation: Babalola M.O. and Balogun J.A. (2013) The Ecology and Potential Health Risk of the Oral Microflora of Python regius and Clelia scyntalina. International Journal of Microbiology Research, ISSN: 0975-5276 \& E-ISSN: 0975-9174, Volume 5, Issue 1, pp.-349-356. DOI : 10.9735/0975-5276.5.1.349-356

Copyright: Copyright@2013 Babalola M.O. and Balogun J.A. This is an open-access article distributed under the terms of the Creative Commons Attribution License, which permits unrestricted use, distribution and reproduction in any medium, provided the original author and source are credited.

\section{Introduction}

Different kinds of microorganisms naturally inhabit the oral cavity of the snakes as their habitat. The oral flora is a mixed ecology constituted predominantly by at least a hundred bacterial species which can be more or less regular residents. Generally, oral bacterial species can be separated into five groups on the basis of their Gram reaction and morphology, namely; the Gram positive cocci, the Gram negative cocci, the Gram positive bacilli, the Gram negative bacilli and the Spirochetes [1]. The other group of microorganism include the fungi which have been less studied.
Owing to the large number of bacteria in the oral cavity, bite wounds are generally subjected to polymicrobial infection, and their treatment is complicated, espe-cially in extensive injuries. Annually, it has been estimated that between 1.2 and 5 million snakebites occur worldwide, causing between 20,000 and 125,000 deaths, commonly in the tropical regions and in areas that are primarily rural or agricultural [2]. In these areas, large numbers of people coexist with numerous snakes. In the United States, five to ten deaths occur per year from snakebites [3].

The oral cavities of poisonous and non-poisonous snakes are colo- 
nized by a large variety of anaerobic and aerobic microorganisms $[4,5]$. Various isolates have been found within abscess sites, suggesting that aerobic bacteria are secondary opportunistic invaders, although anaerobic bacteria are also commonly identified [6]. Therefore, the determination of normal resident flora within the oral cavity of reptiles can be useful in cases of bites, either between two reptiles or a reptile and its handler, as the bacteriology of the wound is likely to reflect the oral flora of the aggressor [7]. A report by Harris and Rogers [8] left the suggestion open that a crocodile bite led to the death of a cage mate due to Stenotrophomonas maltophilia septicemia, possibly introduced at the time of the bite. The microbiota of free ranged wild snakes and snakes in captivity may affect victims of professional accidents, Herpetologists, snake center assistants, Veterinarians, Biologists, Students, collectors and those who raises snakes as pets [9]. Over 50 species of bacteria, including Morganella, Aeromonas, Proteus and Clostridia species, in addition to Staphylococcus aureus, Enterococcus and coagulasenegative Staphylococci were detected in a study of Chinese Cobra by Shek, et al [10]. Since the snake oral bacteria may be inoculated during the snake's bite, bacterial multiplication and infection may occur under favorable conditions [11].

It is important to identify the bacteria in snakes because of the potential pathogenic risks. A strong relationship between microorganisms present in abscesses or in patient' lesions and the ones from snakes' oral cavities have been established [12]. Under healthy conditions, the predominant oral florae of snakes are gram-positive bacteria such as Corynebacterium and Staphylococcus [13]. Reptiles can often act as reservoirs for microorganism mediated diseases in humans and animals. When snakes are infected with microorganisms such as Acinetobacter calcoaceticus, Hafnia alvei, Shigella spp., Klebsiella oxytoca, and Pseudomonas aeruginosa, they have the potential to transmit these infections to humans. Aeromonas hydrophilia infections were transmitted by snake-bites and can induce gastroenteritis, soft tissue infections, and pneumonia in the victim [14].

Snakebite is a serious and important problem in developing countries. For example, snakebite is an occupational hazard for rice field workers, rubber plantation workers, herders and hunters and accidental bites; whereas in industrialized countries, snakes are increasingly popular as pets and most bites are inflicted when snakes are mishandled or attacked. Primarily, snakebites carry the consequences of envenomation leading to lesion formation at the bite site along with extensive tissue necrosis. This dead tissue can acquire secondary infection from bacteria inoculated from the snake's mouth at the time of the bite. Most bacterial wound infections involve gram-negative bacteria, many of which are commensal organisms associated with the aggressor. Bites from non-venomous snakes can also cause injury, as a result of lacerations by the snake's teeth, or subsequent infection. A bite may also trigger a potentially fatal anaphylactic reaction. The number of fatalities attributed to snake bites vary greatly by geographical area. Although deaths are relatively rare in the developed countries, the morbidity and mortality associated with snake bites is a serious public health problem in many developing countries, particularly in rural areas that lack medical facilities. Reptiles are used for various purposes these days, including Entertainment, exhibitions, medicinal applications, pets and laboratory animals. As the international exchange of reptiles has gradually increased, more people have access to these animals, thereby becoming increasingly popular as companion ani- mals [15]. Occasionally, when these pets are presented to Veterinarians for healthcare, conditions with a bacteriological etiology are most commonly reported [16], whether secondary to husbandry deficiencies or as a primary disease. Therefore, studies conducted to identify microorganisms in snakes are very important not only to expand knowledge of the bacteria and fungi species that inhabit the buccal cavity of these animals, but also to obtain understanding of the etiological agents of secondary infections resulting from accidents during handling. Hence, the profile of microbial susceptibility to antimicrobials must be investigated to facilitate adequate treatments in human accidents and ophidian bacterial infections.

Python regius also known as Ball python is a nonvenomous snake species found in Africa and Burma. This is the smallest of the African pythons and is popular in the pet trade. No subspecies are currently recognized [17]. The name Royal python (from the Latin "regius") is based in part on the story that Cleopatra supposedly wore the snake around her wrist [18]. Adult Pythons generally do not grow to more than $90-120 \mathrm{~cm}$ (3.0-3.9 ft) in length, although rarely, some specimens have reached $152 \mathrm{~cm}$ and even $182 \mathrm{~cm}$ (56 feet). Females tend to be slightly bigger than males maturing at an average of 4-4.5 feet. Males usually average around 3-3.5 feet. The build is stocky while the head is relatively small. The scales are smooth and both sexes have anal spurs on either side of the vent. The color pattern is typically black or dark brown with light brown or gold sides and dorsal blotches. The belly is a white or cream that may include scattered black markings [19]. These snakes prefer savannah, open woodlands, scrub forest, and grasslands. This terrestrial species is known for its defense strategy that involves coiling into a tight ball when threatened, with its head and neck tucked away in the middle. Captive bred adults rarely bite. Ball pythons are in the same scientific family as other Boas and Pythons, as such they are constrictors. It is classified into Kingdom: Animalia; Phylum: Chordata; Subphylum: Vertebrata; Class: Reptilia; Order: Squamanta; Sub-order: Serpentes; Family: Pythonidae; Genus: Python; Specie: Python regius [20].

Clelia scyntalina belongs to the family Colubridae of the venomous snakes. It is found commonly in the tropical region. The largest male was known to have attained a total length of $1540 \mathrm{~mm}, 350$ $\mathrm{mm}$ tail length, while the largest female had a total length of 1415 $\mathrm{mm}$ and a tail length of $225 \mathrm{~mm}$. Subscapular always divide throughout the tails, it is higher in males than in females. There is presence of dorsal scale with two apical pits. Juvenile specimens have a different colour pattern from that of the adult due to the ontogenetic changes. It is classified into Kingdom: Animalia; Phylum: Chordata; Subphylum: Vertebrata; Class: Reptilia; Order: Squamata; Intraorder: Alethinophidia; Family: Colubridae; Subfamily: Xenodontinae; Genus: Clelia; Specie: scyntalina.

The gastrointestinal tracts of animals contain numerous species of fungi of whom the niches have been largely unexplored. Until recently, the ecology of microorganisms in the oral cavities of snakes is less studied, most importantly the fungal flora. The fungal flora poses a health threat to the host as well as the victims of snakebites [21]. A global fungal census, which would describe the species of fungi that exist in nature in the context of their habitats, was recommended by Buckley [22]. In Nigeria, there is a paucity of data on the microbial flora of snakes and their pathogenic potentials. To contribute to knowledge on the spectrum of the responsible bacteria and fungal species that potentially contaminate and elicit wound infection from snakebites, this study was designed to determine and 
highlight the pathogenicity of the aerobic bacteria and fungal flora in the oral cavities of two snakes species, and to evaluate the antibiogram of the detected bacteria.

\section{Materials and Methods \\ Sampling}

A total number of three live snakes were recruited in this study. The first snake was, a captive, non-venomous snake, kept in a cage as pet; the second and third were non-captive venomous snakes captured in the wild in Ondo state, Nigeria. However, the third captured snake was later excluded in the study owing to the small size. The non- captive snake, was enclosed in a cloth bag and a small wooden cage. The snakes were not given any food or drug during the period of the research and the species were identified by the handlers and an herpetologist who examined and certified the snakes as healthy.

\section{Collection of Oral Swabs}

The Snakes were taken out of their cage by the snake handlers / Experts and manually restrained throughout the exercise. The mouth of each snake was aseptically opened to facilitate acquisition of the oral swabs. Two oropharyngeal swab samples were collected from each snake using proprietary commercial sterile cotton-tipped swab sticks by aseptically swabbing the oral cavity and carefully transferred into sterile Stuart's transport medium in a conical flask. After the exercise, the Clelia scyntalina snake was released back into the wild. The swab samples were immediately transported to the Microbiology Laboratory of Adekunle Ajasin University, Akungba Akoko, Ondo state, Nigeria for Microbiological Analysis.

\section{Microbiological Analysis of the Swab Samples}

The method of Shek, et al [10] was employed in the analysis. Samples in the Stuarts transport medium were shaken to facilitate even distribution of the organism. With the aid of sterile pipette, $1 \mathrm{ml}$ inoculum was taken from the Stuart medium to seed sterile plates of McConkey Agar (MAC), Blood Agar with 5\% horse blood (BA), Saboraud Dextrose Agar (SDA) and CHROMagar (CHA) employing the pour plate technique, all in duplicates. Negative growth controls were set up to ensure sterility of the media. The plates were allowed to set, labeled, inverted and incubated at $37^{\circ} \mathrm{C}$ for 24 hours for MAC and BA, while the SDA and CHA were incubated at $27^{\circ} \mathrm{C}$ for $72 \mathrm{hrs}$. Cultural and morphological characteristics of the resultant colonies were enumerated, studied and recorded. Distinct colonies of the isolates were picked, and sub-cultured. For bacteria, pure cultures were transferred into Tryptic Soy Agar (TSA) slants, the fungi into SDA slants and preserved for further tests.

\section{Identification of the Bacteria and Fungal Isolates}

The cultural characteristics, cellular morphology by Grams stain, motility tests, pigment production, standard conventional biochemical and phenotypic tests were determined and employed in identifying the bacteria [23] and confirmed using the ABIS online database.

\section{Characterization and Identification of the Fungal Isolates}

Typical discrete colony of each isolate was selected and studied employing colonial and cultural characteristics. Yeast isolates were subjected to a number of biochemical tests and cultured for pseudo mycelium formation [24]. The isolates were further identified based on the microscopic fungal features such as Phialides, septate Sporangiophores, Conidiophores and budding, as previously described [25]. Furthermore, typical isolates were confirmed by culturing the pure isolates on 2\% Malt Extract Agar to achieve enough conidiation, from which suspensions were prepared and inoculated into the BIOLOG FF Microplate (BIOLOG, CA, USA) and incubated at $26^{\circ} \mathrm{C}$ for 5 days. Characteristic fingerprints of each isolate were then read using the BIOLOG Microstation and confirmed with the FF Database. The fungal wet mounts were prepared using Lactophenol-in cotton blue, viewed under the microscope at X40 mag., and the photomicrographs were digitally recorded.

\section{Antibiotic Susceptibility Testing of the Bacteria Isolates}

This test was carried out following the Kirby-Bauer disk diffusion methods of CLSI [26]. Inoculum of each pure isolate was prepared in a direct broth suspension of Nutrient broth, incubated at $35^{\circ} \mathrm{C}$ for $18 \mathrm{hrs}$ and standardized by adjusting its density to match the 0.5 McFarland turbidity standard using Barium sulphate $\left(\mathrm{BaSO}_{4}\right)$. A sterile swab stick was dipped inside the broth suspension into the test tubes, pressed firmly against the wall to remove excess inoculum and used to streak the entire dried surface of sterile Mueller Hinton Agar plates. The streaking was repeated two times by rotating the plates approximately $60^{\circ}$ each time to ensure that every part of the plate was inoculated. The plates were allowed to stay for 15 minutes so as to allow for excess surface moisture to be absorbed before applying the drug impregnated discs. Predetermined commercial (Oxoid) Gram positive bacteria antibiotic discs ( Aug-

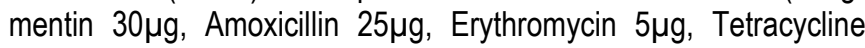
$10 \mu \mathrm{g}$, Cloxacillin $5 \mu \mathrm{g}$, Gentamicin $10 \mu \mathrm{g}$, Cotrimoxazole $25 \mu \mathrm{g}$, and Chloramphenicol $30 \mu \mathrm{g}$ ) were applied to the surface of the inoculated agar plates using a pair of sterile forceps. For the Gram negative

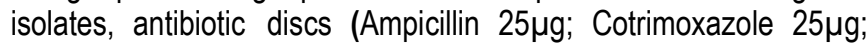

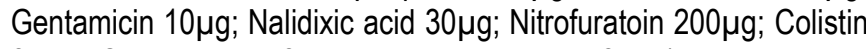
$25 \mu \mathrm{g}$; Streptomycin $25 \mu \mathrm{g}$, and Tetracycline $25 \mu \mathrm{g}$ ) were applied. The plates were inverted and incubated for 18 hours at $37{ }^{\circ} \mathrm{C}$ within 15 minutes of applying the discs. After 18 hours of incubation, the plates were examined and the diameter of the zones of inhibition were measured using a calibrated ruler from the underside of the plate and recorded. The isolates were scored as either sensitive or resistant depending on the diameter of the zone of inhibition.

\section{Results}

[Plate-1] is the photograph of the live Python regius in this study, while [Table-1] and [Table-2] shows the Biochemical characteristics and Probable identities of the bacteria isolates. Nine (9) Gram negative bacteria, representing seven (7) Genera were isolated from the samples analyzed. The bacteria comprised Morganella morganii, Serratia marcescens, Pseudomonas proteolytica and Yersinia enterocolitica ( from Python regius snake), and Serratia liquefaciens, Citrobacter freundii, Proteus mirabilis and Neisseria flora (from Clelia scyntalina snake). Of the Gram negative bacteria, Pseudomonas and Morganella were only detected in the oral cavity of the Python regius while Citrobacter, Proteus and Neisseria were only detected in the Clelia scyntalina. However, Serratia was commonly detected in both species of snake [Table-3]. Similarly, nine (9) gram positive bacteria representing five (5) genera were also detected. The bacteria were Staphylococcus epidermidis, Bacillus mycoides, and Bacillus pumilus (from Python regius ) while Enterococcus feacalis, Bacillus subtilis, Corynebacterium ulcerans and Staphylococcus agalactiae were recovered from Clelia scytalina. Of the gram positive bacteria, Bacillus was predominant in the Python regius while Enterococcus was predominant in the Clelia scyntalina. Enterococcus, Corynebacterium and Streptococcus were not detected in the Python regius. However, Bacillus was common to both 
snakes [Tables-3] and [Table-4]. These results show a great diversity in the bacteria species isolated from the two snakes. Some of these bacteria have been detected in other species of snakes and incriminated as notorious etiology of wound infections secondary to snakebites. However, to my knowledge, this is the first report on these species of snakes. [Table-4] shows the different bacteria isolates from the oral cavities of snakes that were reported to have caused soft tissue infection or abscesses in snakebite wounds [10]. These species of bacteria were considered as potentially pathogenic in this study.

Eight (8) fungal species belonging to six (6) Genera were detected in this study. These comprised Aphanomyces sp., Aspergillus niger, Aspergillus fumigatus, Schizosaccharomyces sp. Candida sp., Monilia sp., Candida krusei and Penicillium sp [Table-3].

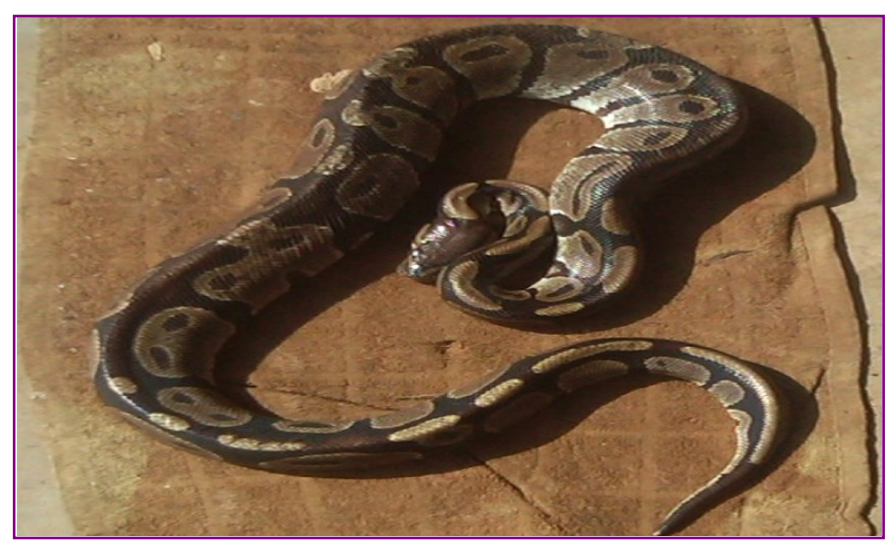

Plate 1- The live Python regius (PR) snake subject in this study

Table 1-Biochemical Characteristics and Identities of Gram negative Bacteria from Python regius and Clelia scyntalina

\begin{tabular}{|c|c|c|c|c|c|c|c|c|c|}
\hline Isolate & PR2 & PR3 & PR5 & PR7 & PR9 & CS2 & CS6 & CS8 & $\operatorname{cs9}$ \\
\hline Catalase test & + & + & + & + & + & + & & + & + \\
\hline Coagulase test & nd & nd & nd & - & - & nd & & nd & nd \\
\hline Urease activity & - & + & - & + & + & - & & + & + \\
\hline Oxidase test & - & - & + & + & + & - & & - & + \\
\hline Indole production & - & + & + & - & + & - & - & - & \\
\hline Methyl Red test & - & + & - & - & - & + & + & + & + \\
\hline Voges Proskauer test & + & - & - & + & + & + & - & - & + \\
\hline Citrate utilization & + & - & - & + & + & + & + & + & + \\
\hline $\mathrm{H}_{2} \mathrm{~S}$ production & - & - & + & - & - & - & + & + & + \\
\hline Ornithine Decarboxylation & + & - & + & nd & nd & + & - & + & nd \\
\hline Lysine Decarboxylation & + & + & - & nd & nd & - & - & - & nd \\
\hline Gelatin hydrolysis & + & - & - & - & - & + & - & + & + \\
\hline Glucose & + & + & + & + & + & + & + & + & + \\
\hline Lactose fermentation & - & - & - & - & - & - & + & - & + \\
\hline Mannitol fermentation & + & - & nd & + & + & nd & & - & + \\
\hline Sucrose fermentation & + & + & + & + & + & + & + & + & + \\
\hline Endospore production & - & - & - & - & - & - & - & - & - \\
\hline Motility test & + & + & - & + & + & + & + & + & - \\
\hline Probable Identity & $\begin{array}{c}\text { Serratia } \\
\text { marcescens }\end{array}$ & $\begin{array}{c}\text { Morganella } \\
\text { morganii }\end{array}$ & $\begin{array}{c}\text { Yersinia } \\
\text { enterocolitica }\end{array}$ & $\begin{array}{c}\text { Pseudomonas } \\
\text { proteolytica }\end{array}$ & $\begin{array}{c}\text { Pseudomonas } \\
\text { proteolytica }\end{array}$ & $\begin{array}{c}\text { Serratia } \\
\text { liquefaciens }\end{array}$ & $\begin{array}{l}\text { Citrobacter } \\
\text { freundii }\end{array}$ & $\begin{array}{l}\text { Proteus } \\
\text { mirabilis }\end{array}$ & $\begin{array}{c}\text { Neisseria } \\
\text { flora }\end{array}$ \\
\hline
\end{tabular}

Legend. +: positive reaction, presence or fermentation, PR: Python regius, - : no reaction, absence or no fermentation, CS: Celia scyntalina, nd: not done

Table 2- Biochemical Characteristics and Identities of Gram positive Bacteria from Python regius and Clelia scyntalina

\begin{tabular}{|c|c|c|c|c|c|c|c|c|c|}
\hline Isolate & PR1 & PR4 & PR6 & PR8 & CS1 & CS3 & CS4 & CS5 & CS7 \\
\hline Catalase test & + & + & + & - & - & + & + & - & - \\
\hline -Coagulase test & - & - & - & - & + & - & - & + & - \\
\hline Urease activity & - & - & - & + & & - & - & & + \\
\hline Oxidase test & + & - & + & + & - & + & - & - & - \\
\hline Indole production & - & - & - & - & & - & - & & + \\
\hline Methyl Red test & - & nd & - & + & & - & - & & \\
\hline Voges Proskauer & + & - & + & - & & + & + & & \\
\hline Citrate utilization & - & + & - & + & + & + & - & + & + \\
\hline $\mathrm{H}_{2} \mathrm{~S}$ production & + & - & + & + & & + & - & - & - \\
\hline Ornithine Decarboxylation & + & nd & + & + & nd & nd & nd & nd & nd \\
\hline Lysine Decarboxylation & + & nd & + & + & nd & nd & nd & nd & nd \\
\hline Gelatin hydrolysis & + & - & + & + & & + & + & & \\
\hline Bile Esculin test & - & nd & - & - & + & - & - & + & - \\
\hline Glucose fermentation & + & + & + & + & + & + & + & + & + \\
\hline Lactose fermentation & + & - & + & - & - & - & - & - & + \\
\hline Mannitol fermentation & + & + & + & + & & + & - & & \\
\hline Sucrose fermentation & + & + & + & + & + & + & + & + & + \\
\hline Endospore Staining & & - & & + & - & + & - & - & - \\
\hline Motility test & + & - & + & - & - & + & - & - & - \\
\hline Probable Identity & $\begin{array}{c}\text { Bacillus } \\
\text { mycoides }\end{array}$ & $\begin{array}{l}\text { Staphlococcus } \\
\text { epidermidis }\end{array}$ & $\begin{array}{c}\text { Bacillus } \\
\text { mycoides }\end{array}$ & $\begin{array}{l}\text { Bacillus } \\
\text { pumilus }\end{array}$ & $\begin{array}{c}\text { Enterococcus } \\
\text { feacalis }\end{array}$ & Bacillus subtilis & $\begin{array}{c}\text { Corynebacterium } \\
\text { ulcerans }\end{array}$ & $\begin{array}{c}\text { Enterococcus } \\
\text { feacalis }\end{array}$ & $\begin{array}{c}\text { Streptococcus } \\
\text { agalactiae }\end{array}$ \\
\hline
\end{tabular}

Legend. +: positive reaction, presence or fermentation; PR: Python regius; - : no reaction, absence or no fermentation; CS: Celia scyntalina; nd: not done 


\section{Discussion and Conclusion}

It is estimated that between 1.2 million and 5.5 million snakebites occur annually. Of the 3,000 snake species that exist in the world, about 600 are venomous and envenoming occurs in about one in every four snakebites. Worldwide, at least 421,000 envenomings and 20,000 deaths from snakebite occur every year but the actual numbers could be as high as 1.8 million envenomings, and 94,000 deaths. The highest burden of snakebite envenomings and death occurs in South and Southeast Asia and in sub-Saharan Africa. India is the country with the highest annual number of envenomings $(81,000)$ and deaths (nearly 11,000) from snakebites [2]. Victims of snakebite may have to undergo a limb amputation because of necrosis and infection. Most studies highlight envenomation at the expense of wound infection as the responsible factor for morbimortality in snakebite cases. However, both factors are critical to the survival of the victims.

Table 3- Microflora of the Oral Cavities of Python regius and Clelia scyntalina

\begin{tabular}{|c|c|c|c|}
\hline $\begin{array}{l}\text { Snake } \\
\text { species/lsolates }\end{array}$ & $\begin{array}{l}\text { Fungal Isolates } \\
\text { (Non venomo }\end{array}$ & $\begin{array}{l}\text { Aerobic Gram } \\
\text { positive bacteria } \\
\text { us) Python regius }\end{array}$ & $\begin{array}{c}\text { Aerobic Gram } \\
\text { negative bacteria }\end{array}$ \\
\hline PR1 & Aphanomyces sp & Bacillus mycoides & Nil \\
\hline PR2 & Aspergillus fumigatus & Nil & Serratia marcescens \\
\hline PR3 & Aspergillus niger & $\mathrm{Nil}$ & Morganella morgann \\
\hline PR4 & Nil & Staph. epidermidis & Nil \\
\hline PR5 & Nil & Nil & Yersinia enterocolitica \\
\hline PR6 & Schizosacch. sp & Bacillus mycoides & Nil \\
\hline PR7 & Nil & Nil & Ps. Proteolytica \\
\hline PR8 & Nil & Bacillus pumilus & Nil \\
\hline PR9 & $\mathrm{Nil}$ & Nil & Ps. Proteolytica \\
\hline \multicolumn{4}{|c|}{ (Venomous) Clelia scyntalina } \\
\hline CS1 & Nil & Entero. faecalis & Nil \\
\hline cS2 & $\mathrm{Nil}$ & $\mathrm{Nil}$ & Serratia liquifaciens \\
\hline cS3 & Candida krusei & Bacillus subtilis & Nil \\
\hline CS4 & Candida sp & Coryn. ulcerans & Nil \\
\hline CS5 & Penicillium $s p$ & Entero. faecalis & Nil \\
\hline $\operatorname{cs} 6$ & Monilia sp & Nil & Citrobacter freundii \\
\hline CS7 & Nil & Strept. agalactiae & Nil \\
\hline CS8 & Nil & Nil & Proteus mirabilis \\
\hline $\operatorname{cs} 9$ & $\mathrm{Nil}$ & $\mathrm{Nil}$ & Neisseria flora \\
\hline Total isolates & 8 & 9 & 9 \\
\hline
\end{tabular}

Table 4- Bacteria known to cause snakebite wound infections or abscesses [10]

\begin{tabular}{|ccc|}
\hline $\begin{array}{c}\text { Aerobic Gram positive } \\
\text { bacteria }\end{array}$ & $\begin{array}{c}\text { Aerobic Gram negative } \\
\text { bacteria }\end{array}$ & Anaerobic bacteria \\
\hline $\begin{array}{c}\text { B-haemolytic streptococci } \\
\text { Coagulase-negative }\end{array}$ & Aeromonas hydrophila & Bacteroides species \\
Staphylococcus** & Citrobacter diversus & \\
Enterococcus & Citrobacter freundii* & \\
Group D Streptococcus aureus & Enterobacter aerogenes \\
Streptococcus viridans ${ }^{* *}$ & Enterobacter agglomerans \\
& Enterobacter species \\
& Escherichia coli \\
& Morganella morgani** \\
& Proteus species ${ }^{* *}$ \\
& Providencia rettgeri \\
& Pseudo. pseudoalcaligenes \\
& Salmonella arizonae \\
& Serratia liquefaciens ${ }^{* *}$ \\
Serratia species & \\
& Yersinia enterocolitica** \\
\hline
\end{tabular}

${ }^{* *}$ Detected in present study.

The incidence of wound contamination and risk of infection by microbial pathogens cannot be underestimated or overemphasized in the event of snakebites. Wound infection is the presence of replicating pathogenic microorganisms within a wound that causes host injury. Generally, primary pathogens of concern include; Staphylococcus aureus, Beta-hemolytic Streptococcus (S. pyogenes, S. agalactiae), E. coli, Proteus, Klebsiella, anaerobes, Pseudomonas, Acinetobacter and Stenotrophomonas.

In this research, the gram negative bacteria species that were isolated from the oral cavities of both venomous and nonvenomous snakes include; Morganella morganii, Serratia marcescens, Proteus mirabilis, Pseudomonas proteolytica, Serratia liquefaciens, Citrobacter freundii, Yersinia enterocolitica and Neisseria flora [Table-3]. The detection of these seven genera of gram negative bacteria corroborate the earlier findings of Shek, et al [10] and Hejnar, et al [11], who in separate studies isolated Morganella, Aeromonas, Proteus mirabilis and Enterobacter from Chinese cobra and Bothrops jararaca respectively. The established bacteria pathogens of wound infections secondary to snakebites that were detected in this present research were Morganella morganii, Proteus mirabilis, Citrobacter freundii, Serratia marcescens, Serratia liquifasciens and Yersinia enterocolitica [Table-4]. These gram negative bacteria have the tenacity to cause serious health complications in the host once the victims are exposed to bite attacks by these species of snakes. In addition to bacteremia and septicemia, these Gram negative bacteria are capable of liberating endotoxin in the soft tissue and blood, during metabolism or autolysis. Absorption and dissemination by the blood of endotoxins of Gram negative bacteria can be accompanied by severe clinical symptoms such as low blood fibrinogen level, hypotension, acute shock and death [27]. Serratia marcescens is involved in hospital acquired infection, urinary tract infection and wound infection. The detection of Serratia in this study corroborates the earlier report of Hsieh and Babl [28] of human infection by Serratia marcescens following a reptile bite, and therefore highlights the potential manifestation of this condition in the event of laceration or bacterial inoculation from Python attack. Royal pythons have teeth that curve backwards (not fangs), designed to help catch and hold the prey whilst the snake wraps and coil around the victim for constriction.

Morganella morganii infections secondary to snakebites have been established while a new case of soft tissue infection by Providencia rettgeri was reported by Cheong, et al [29] in Malaysia. These bacteria have the tenacity to elicit secondary infections in snakebite victims. Consequently, the detection of Morganella morganii in this study lend credence to the previous findings of Valsan, et al [30] who reported a case of snake bite complicated infections by Morganella morganii.

Proteus organisms are implicated as serious causes of infections in humans, along with Escherichia, Klebsiella, Enterobacter, and Serratia species [31]. Proteus mirabilis causes $90 \%$ of Proteus infections and can therefore elicit wound infection in case of bite exposure to this species of snake.

Yersinia enterocolitica has eclipsed Shigella species and approaches Salmonella species and Campylobacter species as the predominant cause of acute bacterial gastroenteritis. Human yersiniosis is attributed to contaminated pork, milk, water, and tofu consumption, as well as blood transfusion. Acute Yersinia enterocolitica infections usually lead to mild self-limiting entero-colitis or terminal ileitis in humans. Symptoms may include watery or bloody diarrhea and fever. After oral uptake, this organism replicate in the terminal ileum and invade Peyer's patches [32]. The detection of these bacteria 
underscores the potential risk of enteric yersiniosis if the meat from the snakes were undercooked before consumption.

Citrobacter freundii is responsible for a number of significant opportunistic hospital acquired infection, respiratory tract, urinary tract, bloodstream, and many other normally sterile sites in patients. Citrobacter freundii represents about $29 \%$ of all opportunistic infections [33]. In addition, isolates of Citrobacter may be resistant to many other antibiotics as a result of plasmid-encoded resistance genes. Of the dozen species, Citrobacter freundii, Citrobacter diversus and Citrobacter amalonaticus are linked to human diseases [34] and the detection of $C$. freundii in this study underscores the probability.

Serratia liquefaciens is an infrequent but increasingly recognized cause of transfusion-related sepsis and is associated with a high rate of mortality. However, the environmental sources of Serratia liquefaciens remained unclear. Serratia liquefaciens has been implicated to be the cause of sepsis. Patients infected with this bacterium are more prone to septic shock which could lead to high mortality rate and this scenario is probable in case of inadequate management of wound infection secondary to Clelia scyntalina bites.

Considering the antibiogram of the isolates, all the Gram negative bacteria were resistant to Ampicillin, Cotrimoxazole, Nalidixic acid and Nitrofurantoin. However, $50 \%$ of the bacteria species were susceptible to Streptomycin, Colistin, and Gentamicin. Serratia marcescens was resistant to all the antibiotics except Nalidixic acid while Morganella morganii, Pseudomonas proteolytica and Citrobacter freundii were resistant to all the antibiotics except Colistin [Table-5] thereby lending credence to the case report of Dufour, et al [31].

Table 5- Antibiogram of Gram negative Bacteria from the Oral cavities of Python reguis and Clelia scyntalina

\begin{tabular}{|c|c|c|c|c|c|c|c|c|c|}
\hline \multirow{2}{*}{\multicolumn{2}{|c|}{ Isolates Identified organisms }} & \multicolumn{8}{|c|}{ zones of inhibition by the antibiotics $(\mathrm{mm})$} \\
\hline & & Amp & Cot & Gen & $\mathrm{Nal}$ & Nit & Col & Str & Tet \\
\hline \multicolumn{10}{|c|}{ Python reguis Snake Samples } \\
\hline PR 2 & Serratia marcescens & 0 & 0 & 0 & 21 & 0 & 0 & 0 & 0 \\
\hline PR 3 & Morganella morganii & 0 & 0 & 10 & 0 & 0 & 10 & 10 & 0 \\
\hline PR 5 & Yersinia enterocolytica & 0 & 0 & 15 & 16 & 15 & 0 & 21 & 14 \\
\hline PR 7 & Pseudomonas proteolytica & 0 & 0 & 0 & 0 & 0 & 11 & 0 & 0 \\
\hline PR 9 & Pseudomonas proteolytica & 0 & 0 & 0 & 0 & 0 & 13 & 0 & 8 \\
\hline \multicolumn{10}{|c|}{ Clelia scytalina Snake Samples } \\
\hline CS 2 & Serratia liquefaciens & 0 & 0 & 15 & 0 & 0 & 13 & 12 & 7 \\
\hline CS 6 & Citrobacter freundii & 0 & 0 & 0 & 10 & 0 & 15 & 0 & 0 \\
\hline $\operatorname{CS} 8$ & Proteus mirabilis & 0 & 0 & 16 & 0 & 0 & 15 & 16 & 13 \\
\hline $\operatorname{Cs} 9$ & Neisseria flora & 0 & 0 & 16 & 0 & 0 & 14 & 17 & 15 \\
\hline
\end{tabular}

The detected gram positive bacteria from the oral cavities of both snakes include; Enterococcus fecalis, Staphylococcus epidermidis, Bacillus subtilis, Corynebacterium ulcerans, Streptococcus agalactiae, Bacillus mycoides, and Bacillus pumilus [Table-3] of which the established pathogens [Table-4] in snakebite wound complications were Staphylococcus epidermidis, Enterococcus faecalis and Streptococcus agalactiae. These results corroborate the earlier findings of Shek, et al [10] and Chalya, et al [35]. Bacillus subtilis are naturally found in the soil and vegetation, it grows in the mesophilic temperature range of $25-35^{\circ} \mathrm{C}$ and has evolved the formation of stress-resistant endospores that allow survival under harsh conditions. All these factors could have facilitated the survival and detection of the bacteria in the oral cavities of the snakes.

In a previous report by Kerrigan [36], Enterococcus faecalis and Staphylococcus epidermidis were incriminated in the development of abscesses from snakebites. The detection of Enterococcus faecalis and Staphylococcus epidermidis in this study highlights the potential risks associated with these organisms in complicating snake bite wounds. Several virulence factors such as Cytolysin and plasmid encoded "aggregation substance" are thought to contribute to Enterococcus faecalis bacteremia infections. Of the Gram positive bacteria isolates in this study, Staphylococcus epidermidis was susceptible to the tested antibiotics except Amoxicillin and Cloxacillin while Enterococcus faecalis, Bacillus mycoides, Bacillus pumilus, Bacillus subtilis, and Streptococcus agalactiae were all resistant to the antibiotics except Gentamicin [Table-6]. These findings suggest that multidrug resistant Enterococcus may not be limited to clinical isolates but naturally present as environmental strains.

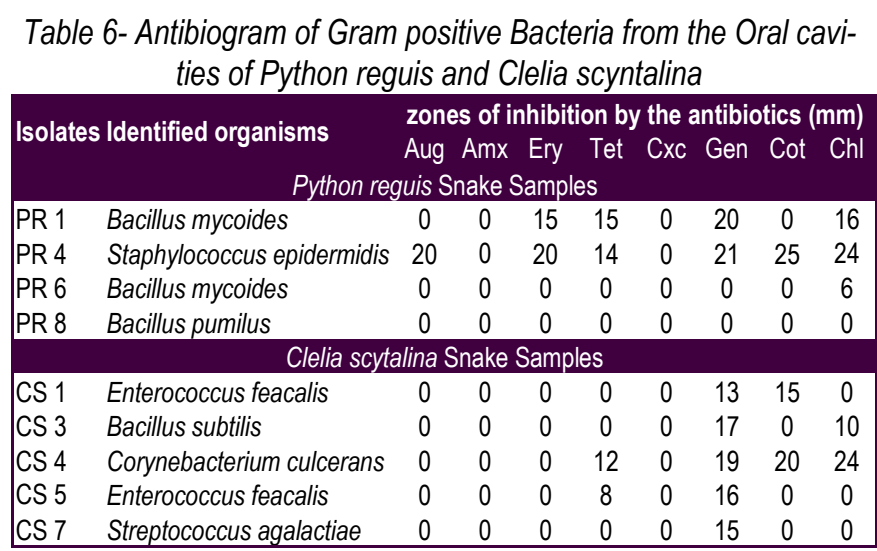

Cutaneous diphtheria is another form of diphtheria ( a potentially life threatening bacteria infection that classically infect the mucous membrane of the nose and throat) which causes typical pain, redness, and swelling associated with other bacterial skin infections and may progress to chronic ulcers. A cat bite human illness attributable to toxigenic Corynebacterium ulcerans was reported by Berger, et al [37]. Therefore, the detection of $C$. ulcerans in this study represent the first detection of this pathogen in the oral cavity of the snake, aside from cats [38] which were often implicated in the transmission of the pathogen to humans.

Wound provides an excellent medium for bacterial growth. This virulent toxigenic Corynebacterium strain may elicit cutaneous diphtheria in a susceptible snakebite victim.

Various combinations (synergy) of bacterial species result in more host damage. For example, the pathogenic synergy between Group B Streptococcus (S. agalactiae) and Staphylococcus aureus. This characteristic outcome can be extrapolated to the existence of multipathogens comprising Corynebacterium ulcerans, Enterococcus faecalis and Streptococcus agalactiae in the Clelia scyntalina, and the potential damaging outcome when inoculated into a snakebite victim. Furthermore, the synergistic outcome of the virulence factors of the pathogens can further worsen the infection. For example the production of Hyaluronidase by Streptococcus pyogenes; proteases by Staphylococcus aureus and Pseudomonas aeruginosa; toxins by Streptococcus pyogenes and Staphylococcus aureus, can result in hemolysis, coupled with endotoxin by gram negative bacteria. In addition, synergy between different bacterial factors and host' factors can result in serious host damage and complications. Local factors that increase chances of wound infection include Large wound area, Anatomic location (distal extremity, perineal), Necrotic tissue and Mechanism of injury (bites, perforated viscus) while the Systemic factors that increase chances of wound infection are Vas- 
cular disease, Edema, Malnutrition, Diabetes, Alcoholism and so on [39]. Aside the inoculation of the Snake's venom into the victim, the proteolytic properties of the venom causes extensive tissue destruction and devitalization, thus predisposing the wound to bacterial and fungal infections from the snake's indigenous oral flora.

The recent increase in numbers of people with immunodeficiencies has caused an equally dramatic surge in the incidence of fungal infections particularly Aspergillus and Penicillium species. Aspergillosis is recognized as the most common fungal infection of the immunocompromised patients. From the results of this research, eight (8) fungal species were detected from the oral cavities of the two (2) snakes species. The fungi species included Aphanomyces sp., Aspergillus fumigatus, Aspergillus niger, Schizosaccharomyces sp., Candida sp., Candida krusei, Penicillium sp. and Monillia sp. [Table -3] and [Plate-2], [Plate-3], [Plate-4], [Plate-5], [Plate-6], [Plate-7].

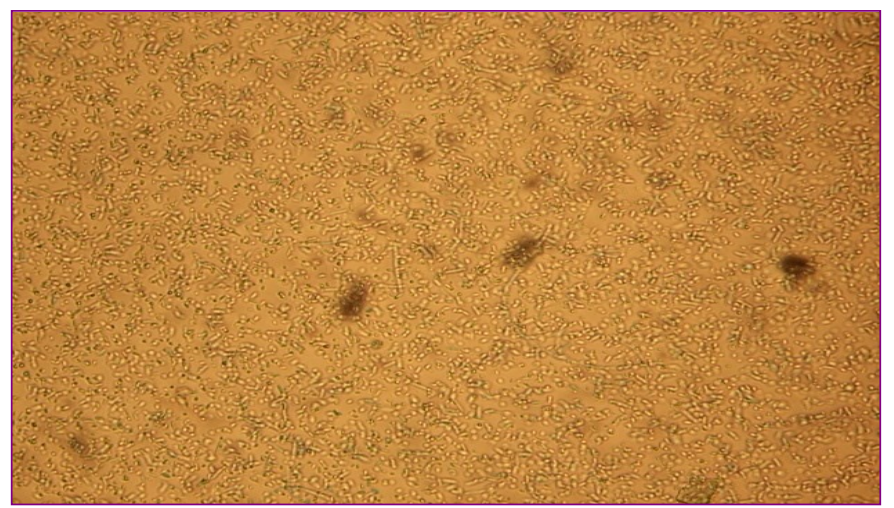

Plate 2- Micrograph of Candida sp (CS4) from Clelia scyntalina.

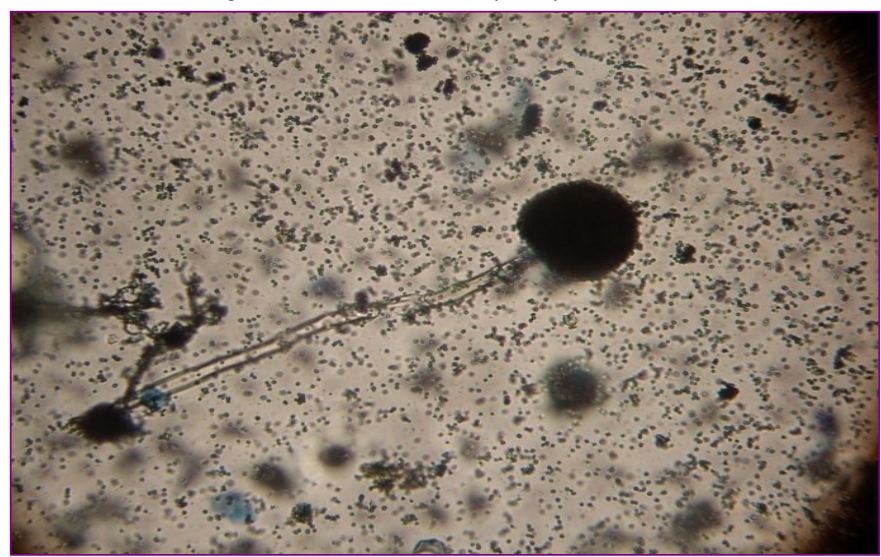

Plate 3- Micrograph of Aspergillus niger (PR3) from Python regius

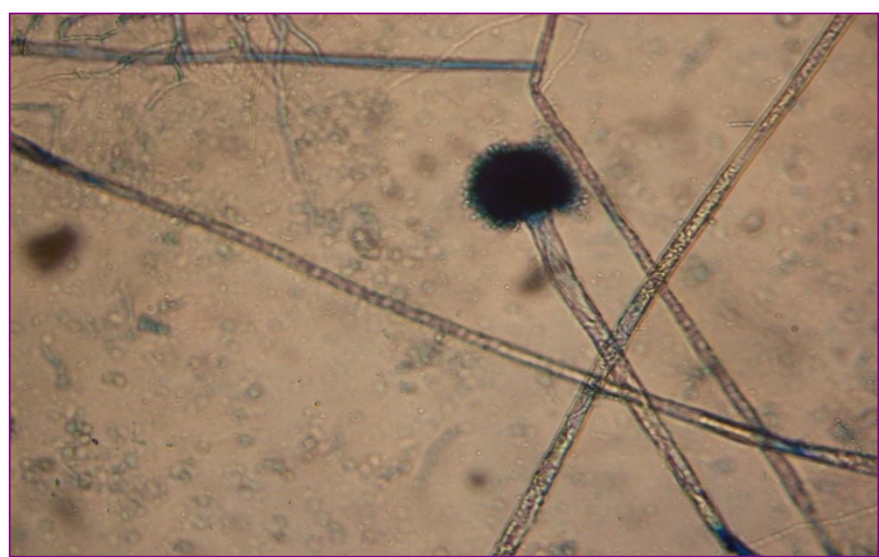

Plate 4- Micrograph of Aspergillus fumigatus (PR2) from P. regius

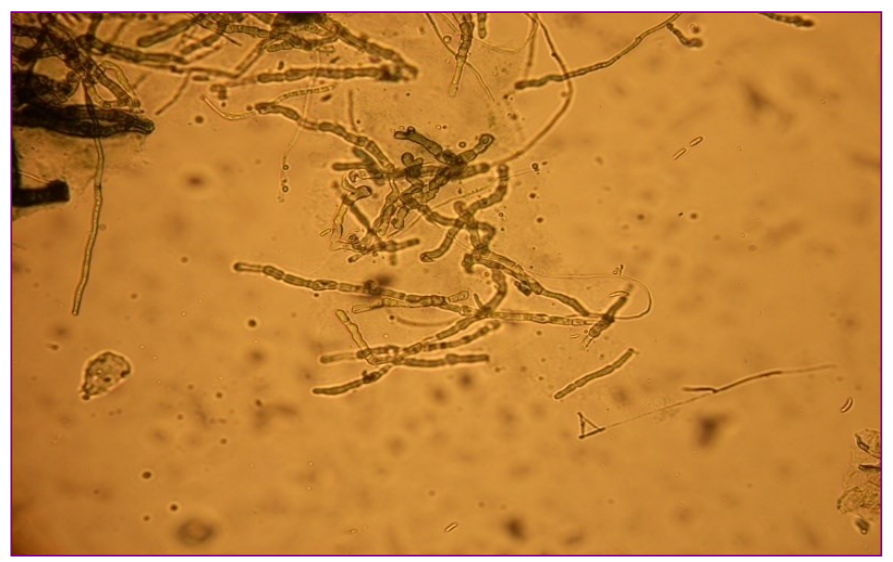

Plate 5- Micrograph of Monilia sp (CS6) from Clelia scyntalina

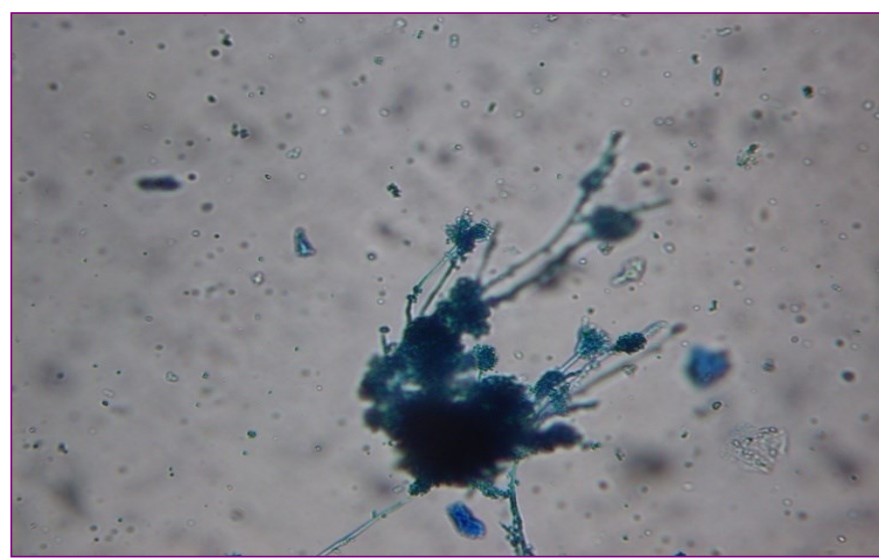

Plate 6- Micrograph of Penicillium sp (CS5) from Clelia scyntalina

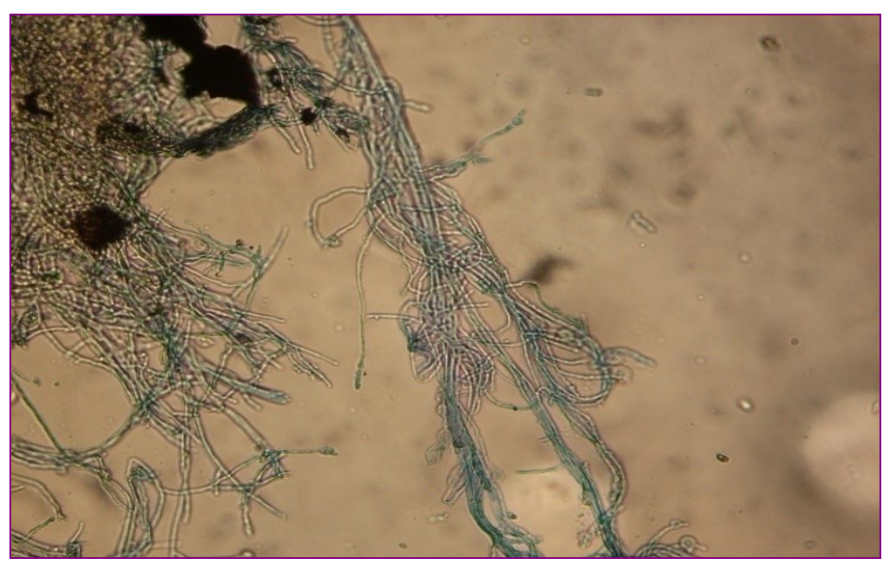

Plate 7-Micrograph of Aphanomyces sp (PR1) from Python regius.

Only little is known about the oral fungal flora in snakes, although some detected fungal species were reported as causative agent of numerous infections in reptiles. Therefore this report is one of the foremost and recent findings of the fungal flora of the oral cavities of these snake species in Africa. One limiting factor in the growth of fungi in man is the body temperature. Contrarily, the poikilothermic nature of snakes may enhance the growth of these fungi in the oral cavity. The fungal species therefore find the ecological niche quite favorable to thrive, owing to fluctuations in the body temperature of reptiles within the mesophilic range, unlike the homoeothermic humans. Consequently, the snake species may serve as reservoirs of potential human fungal pathogens, may transmit the fungal pathogens to humans during accidental snake bites, and elicit potential mycotic infections particularly in immunocompromised victim. Can- 
dida $s p$. is one of the notorious pathogens responsible for septicemia, and superficial mycotic infections of the skin, the nail, the hair, and mucous membranes. Therefore the detection of Candida sp and Candida krusei in the Clelia scyntalina predisposes the susceptible victim to septicemia if the snakebite is not properly managed. This is highly probable because the healthcare provider focuses treatment at the venom and probably the bacterial infection, inadvertently neglecting the potential fungal pathogens.

The findings of this research upholds the hypothesis that the oral bacteria flora of snakes vary between different species and different geographical regions. However contrary to the assertion that there appears to be a lower bacterial load within the oral cavity of nonvenomous snakes than the venomous ones $[10,14]$, the diversity of the detected pathogenic bacteria and fungi were comparable in both the Clelia scyntalina and the Python regius in this study. Simultaneously, the detected fungal species were pathogenic, and the bacteria species were multidrug resistant pathogenic strains. Therefore, the combination potentiates serious health risk, consequent upon snakebite associated wound infections and treatment failures, whose outcome may incur longer hospitalization, higher cost of healthcare, morbidity, deformity and mortality.

\section{Acknowledgements}

The Authors declare no competing interests. We acknowledge the assistance of Mr Akele, $\mathrm{O}$. and Adebumiti, B. in conducting the photomicrograph and antibiotic susceptibilities respectively.I

\section{References}

[1] Madinier I. (1991) J. Biol Buccale, 19(1), 3 -15.

[2] Kasturiratne A.A., Wickremasinghe R., de Silva N., Gunawardena N.K., Pathmeswaran A., Premaratna R., Savioli L., and de Silva J.H. (2008) PLoS Medicine, 5 (11), 218.

[3] Brook I. (2009) Current Infectious Disease Reports, 11(5), 389395.

[4] Arroyo O., Bolaños R. and Muñoz G. ( 1980) Bull. Pan-Am. Health Org., 14, 280-285.

[5] Blaylock R.S. (2001) Onderstepoort Journal of Veterinary Research, 68, 175-182.

[6] Brown J.D., Richards J.M., Robertson J., Holladay S. and Sleeman J.M. (2004) Journal of Wildlife Diseases, 40, 704-712.

[7] Kelsey J., Ehrlich M. and Henderson S.O. (1997) American Journal of Emergency Medicine, 15, 536-537.1

[8] Harris N.B. and Rogers D.G. (2001) Journal of Veterinary Diagnostic Investigation, 13, 255-258.

[9] Chirio I. (2009) Soc. Herp. France, 132,13-41.

[10]Shek K.C., Tsui K.L., Lam K.K., Crow P. and Ades G. (2009) Hong Kong Medical Journal, 15, 183-190.

[11]Hejnar P., Kolár M. and Sauer P. (2010) Folia Microbiologica, $55,83-87$.

[12]Quiroga M., Avila-Agüero M.L. and Faingezicht I. (2000) J. Venom Anim. Toxins, 6(2), 261-70.

[13]Sattler C.A., Mason E.O., Kaplan J.R. (2000) Clin. Infect. Dis., 31, 1321-1330.

[14]Abbott S.L. and Janda J.M.( 2010) Clin. Microbiol. Rev., 23, 3573.

[15]Taddei S., Dodi P.L., Diianni F., Cabassi C.S., Cavirani S. (2010) Veterinary Record, 167, 29-30.
[16]Parè J.A., Sigler L., Rosenthal K.L., Mader D.R. ( 2006) Reptile Medicine and Surgery. 2nd Ed. Saunders Elsevier, 217-239

[17]Mccurle H.O., Kevin G. (2005) Nat. Hist. Books, 300.

[18]Barker D.G. and Barker T.M. (2006) VPI Library, 320.

[19]Mehrtens J.M. (1987) Living Snakes of the World in Color, Sterling Publishers, New York, 480.

[20]Boulenger G.A. (1893) Catalogue of the Snakes in the British Museum, Nat. Hist., London, 48.

[21]Carvalho V.M., Ramos M.C., Costa E.O. and Diniz I.S. (2011) Arq. Bras. Med. Vet. Zootec., 53(4),1-2.

[22]Buckley M. (2008) Colloquium Report AAM, ASM, Washington D.C., $1-48$.

[23]Holt J.G., Krieg N.R., Sneath H.A., Stanley J.T. and Williams S.T. (2000) Bergeys Manual of Determinative Bacteriology, 9th ed., Lappinscott, Williams and Wilkings, Baltimore USA. 751246.

[24]Lodder J. (1970) The Yeasts: A Taxonomic Study, 1st ed. Amsterdam, Holland.

[25]Harrigan W.F. and McCance M.F. (1976) Laboratory Methods in Food and Dairy Microbiology, 7th ed., Churchill Livingstone, New York, 250-262.

[26]Clinical and Laboratory Standard Institute (2005) Performance for Antimicrobial Susceptibility Testing, 15th Informational Supplement., 3(1), M100-515.

[27]Babalola M.O. and Akinyemi A. (2012) Scottish Journal of Arts, Social Sciences and Scientific Studies, 2(II), 14 -25.

[28]Hsieh S. and Babl F.E. (1999) Clinical Infectious Diseases, 28, 1181-1182.

[29]Cheong C.Y., Lee C.K. and Zuki Z. (2010) Malaysian Orthopaedic Journal, 4(1), 53-55.

[30]Valsan C., Rao T. and Sathiavathy A. (2008) The Internet Journal of Infectious Diseases, 6(2).

[31]Dufour T.O., Gué M.D. and Virginie S.I. (2001) Biochemistry, 40 (39), 1938-1945.

[32]Santarpia L.B., Benvenga S.O., Trimarchi F.S. and Guarneri F. (2006) Thyroid, 16(3), 225-236.

[33]Shao J., Tompkins R.G., Ausubel F.M. (1995) Science, 268 (5219), 1899-1902.

[34]English J.C., Whalen J.G. and Mully T.W. (2007) Archives of Dermatology, 143(1), 124-125.

[35]Chalya P.L., Mchembe M., Gilyma J.M. (2011) Journal of Surgery, 16(1), 46-51.

[36]Kerrigan K.R. (1992) Trop. Doct., 22, 158-160.

[37]Berger A., Schmidt-Wieland T., Huber I. and Sing A. (2011) Annals of Internal Medicine, 155(9), 646- 648.

[38]Wagner K.S., White J.M., Crowcroft N.S., De Martin S., Mann G. and Efstratiou A. (2010) Epidemiol. Infect., 138, 1519-1530.

[39]Dow G., Browne A. and Sibbald R.G. (1999) Ostomy/Wound Management, 45(8), 23-40. 